Article

\title{
Quantifying the Recoverable Resources of Companion Metals: A Preliminary Study of Australian Mineral Resources
}

\section{Gavin M. Mudd ${ }^{1, *}$, Mohan Yellishetty ${ }^{2}$, Barbara K. Reck ${ }^{3}$ and T. E. Graedel ${ }^{3}$}

1 Environmental Engineering, Department of Civil Engineering, Monash University, Clayton, VIC 3800, Australia

2 Mining Engineering, Department of Civil Engineering, Monash University, Clayton, VIC 3800, Australia; E-Mail: Mohan.Yellishetty@monash.edu

3 School of Forestry and Environmental Studies, Yale University, New Haven, CT 06511, USA; E-Mails: barbara.reck@yale.edu (B.K.R.); thomas.graedel@yale.edu (T.E.G.)

* Author to whom correspondence should be addressed; E-Mail: Gavin.Mudd@monash.edu; Tel.: +61-3-9905-1352.

External Editor: Damien Giurco

Received: 12 December 2013; in revised form: 17 November 2014 / Accepted: 17 November 2014 / Published: 1 December 2014

\begin{abstract}
The long-term availability of mineral resources is crucial in underpinning human society, technology, and economic activity, and in managing anthropogenic environmental impacts. This is increasingly true for metals that do not generally form the primary product of mines ("host" metals), such as copper or iron, but are recovered as by-products (or sometimes co-products during the processing of primary ores). For these "companion" metals, it is therefore useful to develop methodologies to estimate the recoverable resource, i.e., the amount that could, if desired, be extracted and put into use over the next several decades. We describe here a methodological approach to estimating the recoverable resources of companion metals in metal ores, using preliminary data for some particular host/companion pairs in Australia as examples.
\end{abstract}

Keywords: mineral resources; sustainable mining; companion metals; Australia 


\section{Introduction}

All economic geologists and exploration and mining companies are aware that the majority of metals are recovered as by-products or co-products from parent ores. These by-products have been referred to as "companion metals", in contrast to "host metals", the main metals of the parent ores [1]. A working list of the companion metals and their typical hosts appears in Table 1. Companion metal extraction is dependent on the availability of technology to recover those metals during or following processing of the host metal ore, as well as the economic attractiveness of companion or by-product metal recovery. These potential constraints may limit the production of desirable companion metals, a fact that renders it important to make a realistic estimate of anticipated companion metal availability. Among the parameters that need to be assessed are the size and type of the host metal ore bodies, the typical abundances of companion metals in the host or hosts, typical recovery efficiencies for these companion metals (especially given the different technologies used), and models of the relative costs and value of companion metal recovery.

Table 1. The most important host metals and their companions $[2,3]]^{\#}$.

\begin{tabular}{cccc}
\hline Main host metal & Companion metal(s)* & Main host metal & Companion metal(s)* $^{*}$ \\
\hline $\mathrm{Ni}$ & $\mathbf{S c}, \mathbf{C o}, \mathbf{R u}, \mathbf{R h}, \mathbf{P d}, \mathbf{O s}, \mathbf{I r}$ & $\mathrm{Al}$ & $\mathrm{V}, \mathbf{G a}$ \\
$\mathrm{Cu}$ & $\mathrm{Co}, \mathbf{A s}, \mathbf{S e}, \mathbf{M o}, \mathrm{Ag}, \mathbf{T e}, \mathbf{R e}, \mathrm{Au}$ & $\mathrm{Ti}$ & $\mathbf{Z r}, \mathbf{H f}$ \\
$\mathrm{Fe}$ & $\mathrm{V}, \mathrm{Sc}, \mathbf{L a}, \mathbf{C e}, \mathbf{P r}, \mathbf{N d}$ & Rare Earth Elements & Y, Th \\
$\mathrm{Zn}$ & $\mathbf{G e}, \mathrm{Ag}, \mathbf{C d}, \mathbf{I n}, \mathrm{Tl}$ & $\mathrm{Mo}$ & $\mathrm{Re}$ \\
$\mathrm{Pb}$ & $\mathrm{Ag}, \mathbf{S b}, \mathbf{T l}, \mathbf{B i}$ & $\mathrm{Au}$ & $\mathrm{Ag}$ \\
\hline
\end{tabular}

Notes: * Bold face means that the host metal indicated is the principal source $(>50 \%)$ of the companion.

\# Metals are listed in atomic number order (left descending to right descending order). Note: Some host metal ores contain more than one primary host metal, often termed co-products, such as $\mathrm{Cu}-\mathrm{Au}, \mathrm{Pb}-\mathrm{Zb}, \mathrm{Ni}-\mathrm{Cu}$, with the above table being indicative only.

In general, the extraction of metals from mineral ores requires various combinations of mining, milling, smelting and refining, either through physical, pyrometallurgical or hydrometallurgical techniques $[4,5]$. The stage at which companion metals are concentrated and extracted will depend on the primary host ores and the processing methods employed. For example, Ga can be extracted from the leach solutions in an alumina refinery, while $\mathrm{Zr}$ is a co-product of Ti during mining of mineral sands and $\mathrm{Hf}$ is a by-product of $\mathrm{Zr}$ refining. Other companion metals are concentrated during flotation at the mill (e.g., $\mathrm{Re}$ in Mo concentrates during $\mathrm{Cu}$ ore milling, In $\mathrm{Zn}$ concentrates during $\mathrm{Pb}-\mathrm{Zn}$ ore milling) and subsequently extracted during smelting and/or refining of such concentrates. Thus, for many companion metals, their production is intimately tied to smelters and refineries, which often process concentrates from multiple mines and are quite distant from the source mines. It should also be noted, however, that detailed information on the production of companion metals is often very limited and sparse in nature (e.g., [2,3]). Finally, mines are commonly only paid for the primary payable metals contained in concentrates (such as $\mathrm{Cu}, \mathrm{Au}, \mathrm{Zn}, \mathrm{Pb}, \mathrm{Ag}$ ), and depending on the smelter or refinery which the concentrates are sold to, this may allow for extraction of some companion metals if the site has infrastructure in place (e.g., In and $\mathrm{Cd}$ at a $\mathrm{Zn}$ refinery, $\mathrm{Se}$ and $\mathrm{Te}$ at a $\mathrm{Cu}$ smelter and/or refinery). 
Similarly, if say a $\mathrm{Cu}$ deposit is developed using different technology, such as a heap leach operation rather than milling to produce concentrates, then the associated companion metals (e.g., Mo, Re, Se, Te) will not be extracted at all.

As can be seen, evaluating the long-term prospects for different metals is an exercise in geology, technology, and economics - all factors that can be quite variable over time. For many companion metals there are no reliable estimates of likely ore reserves or mineral resources [6]. The U.S. Geological Survey (USGS) publishes annual estimates of global reserves for several major metals (e.g., $\mathrm{Fe}, \mathrm{Cu}, \mathrm{Pb}, \mathrm{Zn}, \mathrm{Au}$ ) as well as selected companion metals (e.g., Sb, Cd, Co, Se), but many companion metals have no such estimates (e.g., Ga, Ge, In, Sc) [7]. It is therefore useful to prepare estimates, even if approximate, of what might be termed the "recoverable resource" for a particular companion metal.

\section{Hybrid Methodology for Quantifying Recoverable Companion Metals}

\subsection{Mineral Resource Reporting}

There are a variety of common terms used to describe or quantify economic mineral resources, including some with statutory significance in many countries. A mineral resource can, at its simplest, be considered as something that can generate inherent value to society. The resource is identified through geological exploration and, when considered profitable, can be mined to produce a given mineral or metal. The challenge is to ascertain and describe which deposits constitute a potentially profitable mineral resource. Such a determination can vary due to market conditions (e.g., supply/demand and price fluctuations), input costs (e.g., fuels, labour), ore processability (e.g., how easily the minerals can be extracted with different technologies and the relative costs and benefits involved in targeting mineral processing for individual metals, such as $\mathrm{Ni}$ over $\mathrm{Co}$ ), capital and operating costs, or social issues (e.g., bans on mining in national parks, political and trade sanctions).

Given the complexity of justifying a mineral deposit as profitable and the need to provide clear justification and communication of such results to the public and investors (as most mining companies are publicly listed on their respective national stock exchanges), much of the global mining industry uses formal codes for assessing and reporting mineral resources. In general, all mining companies listed on a stock exchange are required to use their respective national code (e.g., Australian uses the JORC Code, [8,9]; South Africa uses SAMREC, [10]; Canada uses NI43-101, [11]).

The two primary aspects which these codes consider are geological and economic probability in claiming a mineral resource as profitable. A range of important "modifying factors" are compulsory to consider: mining, metallurgical, economic, marketing, legal, environmental, social, and governmental. There are two primary categories used to classify a mineral deposit - ore reserves and mineral resources. The typical distinction is that ore reserves have a very high economic and geologic probability of profitable extraction, while mineral resources have a reasonable geological probability but are less certain economically. The JORC definitions are:

- Ore Reserves - assessments demonstrate at the time of reporting that profitable extraction could reasonably be justified. Ore Reserves are sub-divided in order of increasing confidence into Probable Ore Reserves and Proved Ore Reserves. 
- Mineral Resources - the location, quantity, grade, geological characteristics, and continuity of a mineral resource are known such that there are reasonable prospects for eventual economic extraction, although not all modifying factors have been assessed and hence some uncertainty remains. Mineral Resources are sub-divided, in order of increasing confidence, into Inferred, Indicated, and Measured categories.

In order to assess the long-term future of companion metal mining, a realistic approach is to compile total mineral resources as reported by various companies and mines - that is, including all measured, indicated, and inferred resources. This is due to the fact that at many of the world's giant or long-lived projects, ore reserves commonly represent a minority of the known geological orebody, while mineral resources are sufficiently geologically understood to allow long-term project planning. Over time, it is very common for mineral resources to be upgraded to ore reserves, and subsequently mined, as shown for $\mathrm{Cu}$ [12,13], $\mathrm{Co}$ [14], Ni [15] and platinum group elements (PGEs) [16].

Overall, mineral resources are a more robust basis to examine the future prospects of companion metal mining than ore reserves alone - and this could help to demonstrate more powerfully that there are sufficiently known companion metals available for several decades, with strong prospects for continued growth in recoverable metals. This approach has recently been demonstrated for $\mathrm{Cu}$ [13], Co [14], uranium (U) [17], Ni [15] and rare earth elements (REEs) [18].

\subsection{Quantifying Economic and Recoverable Mineral Resources}

For this study, we compile an extensive data set of Australian mineral resources by individual project/deposit, as reported under the statutory resource codes using 2012 data or the most recent report. Given the variable data sources and reporting, a basic data quality classification has been adopted, to indicate the approximate reliability of the mineral resource data:

- High - a current code-based mineral resource is reported (from 2012, but if not available, generally within the last five years).

- Medium - a current code-based mineral resource is available for ore tonnage, but no ore grade is reported and an alternate literature source is used (e.g., technical report, journal paper). These resources are similar in nature to existing mines and thus have a reasonable prospect of being considered for future extraction.

- Low - no current code-based mineral resource for ore tonnage or ore grade is reported, and alternate literature sources are used (e.g., technical report, journal paper); these resources are not considered similar in nature to existing mines and thus are highly speculative.

Although a typical recovery rate should be applied to each deposit based on ore type and probable processing configuration, as completed recently for Co by Mudd et al. [14] and shown in Table 2, these data are not yet available for Australian deposits and mines. The actual extent of companion metal recovery over time, of course, will continue to depend on economics (supply/demand, prices, etc.), processing technology, environmental and social constraints, and so on.

Finally, we only present data where companion metal data has been reported as part of a formal mineral resource estimate. Future work will focus on examining geological data to derive an approximate grade for deposits known to contain companion metals but where no grade data is reported for the 
mineral resource, with such resources given a medium reliability classification (see [14]). A similar approach will be adopted for companion metals in historic tailings, with these resources given either a medium or low reliability depending on the extent and uncertainty of data.

The methodology adopted herein allows a more comprehensive picture of potentially recoverable companion metals beyond the current constraints of strict code-based reporting. Assessing the supply and demand of companion metal resources is important to enable the identification of any changes that may have significant repercussions for the global economy, technology needs, and the environment - and our hybrid resource accounting methodology is directed to this objective.

\section{Quantifying Australian Companion Metal Resources}

\subsection{Summary of Australia's Principal Mines by Commodity and Companion Metals}

A summary of Australia's major metal mines is given in Table 3, showing 2012 mine production, mining methods, mine gate products (such as concentrate or smelted and/or refined metals) and known by/co-products (e.g., Au, Ag). Nearly all of the principal host metals of Table 1 are listed. As can be seen, most metals are still primarily mined for their host metal, such as copper, with only high value metals such as $\mathrm{Au}$ or $\mathrm{Ag}$ recovered as part of processing. It is known that modest amounts of $\mathrm{Cd}$ from $\mathrm{Zn}$ refineries or Se from $\mathrm{Cu}$ smelters is recovered in Australia, but these metal flows are not reported in Australia (see $[19,20])$. Curiously, however, the USGS publishes estimates for some Australian companion metals production (e.g., refined $\mathrm{Cd}, \mathrm{Co}$ ) but considers data insufficient for others (e.g., Se) [2]. In general, there remains a complete dearth of Australian recorded production for most companion metals either from Australian mines and smelters/refineries or derived from exported concentrates; future research will need to investigate this in detail.

An important aspect is that, like the grades of processed ores [21], overall mineral resource grades are in long-term decline, with examples of $\mathrm{Pb}, \mathrm{Zn}, \mathrm{Ag}, \mathrm{Cu}$ and $\mathrm{Au}$ shown in Figure 1. For $\mathrm{Pb}-\mathrm{Zn}$, the greater decline in $\mathrm{Pb}$ grades is due to the constraints on $\mathrm{Pb}$ demand (i.e., substitution in paints, removal from petrol) and the greater focus on $\mathrm{Zn}$, with the increase in average grades in the 1990s reflecting the discovery of the higher grade Century deposit in western Queensland. For $\mathrm{Cu}$, the increase in the $1950 \mathrm{~s}$ is due to the growing dominance of Mt Isa (averaging $\sim 3 \% \mathrm{Cu}$ ) over the lower grade $\mathrm{Cu}-\mathrm{Au}$ projects at Mt Lyell and Mt Morgan $(\sim 1 \% \mathrm{Cu})$, although grades have declined substantially since the late 1980s due the discovery and/or development of a large number of average to low grade projects (e.g., Cadia, Boddington, Telfer, Northparkes) as well as the growing size of Olympic Dam. Overall, during the past century, ore grades for these metals have decline by almost one order of magnitude. 
Table 2. Available mineral processing data for Australian Co-producing mines (2012 data, updated from [14]; Australia only).

\begin{tabular}{|c|c|c|c|c|c|c|c|c|c|c|c|}
\hline Mine/Project & Ore type & Primary process & Mt ore & $\% \mathrm{Ni}$ & $\% \mathbf{C u}$ & $\% \mathrm{Co}$ & kt Ni & kt $\mathbf{C u}$ & t Co & Co recovery & Companies \\
\hline Murrin Murrin, Australia & Ni laterite & HPAL+Heap Leach & $\sim 3.0$ & $\sim 1.3$ & - & $\sim 0.1$ & 33.4 & - & 2400 & $\sim 79 \%$ & Glencore (through Minara Res.) \\
\hline Cosmos-Sinclair, Australia & Mag. sulfide & Flotation & 0.726 & 2.12 & $n d$ & $n d$ & 11.7 & 0.6 & 322 & $n d$ & Xstrata \\
\hline Savannah, Australia & Mag. sulfide & Flotation & 0.672 & 1.28 & 0.69 & 0.067 & 7.4 & 4.4 & 401 & $88.6 \%$ & Panoramic Resources \\
\hline Kambalda Group, Australia ${ }^{d}$ & Mag. sulfide & Flotation & $\sim 1.13^{\mathrm{d}}$ & $\sim 2.94^{\mathrm{d}}$ & $\sim 0.24^{\mathrm{d}}$ & $\sim 0.03^{\#, \mathrm{~d}}$ & $27.7^{\mathrm{d}}$ & $2.1^{\mathrm{d}}$ & $\sim 168^{\mathrm{d}}$ & $\sim 50 \%{ }^{d}$ & Various $^{\mathrm{d}}$ \\
\hline
\end{tabular}

Notes: All data are from respective company annual and/or quarterly reporting; Data in bold-italics are indirectly estimated based on other reported data (mainly historical data); $n d-$ no data; ${ }^{*}$ mineral resource ore grade; ${ }^{d}$ The Kambalda mill is owned by BHP Billiton while all mines are owned by junior companies who sell ore to Kambalda, and since the 2005 takeover of WMC by BHP Billiton, no production data for the Kambalda mill has been reported; the data shown are based on all junior companies and the authors' estimates (e.g., [21]).

Table 3. Overview of metal mining production data in Australia and typical companion metals extracted (2012 data).

\begin{tabular}{|c|c|c|c|c|c|c|}
\hline $\begin{array}{c}\text { Primary ores/Host } \\
\text { metal(s) }\end{array}$ & Number of mines & 2012 production & Mining methods & $\begin{array}{c}\text { Ore processing } \\
\text { methods }\end{array}$ & Major mines & $\begin{array}{l}\text { Main companion } \\
\text { metals/minerals }\end{array}$ \\
\hline Bauxite & 5 & 76.28 Mt saleable & \multirow{2}{*}{ open cut } & Beneficiation & Weipa, Worsley-Boddington, & \multirow{2}{*}{ none } \\
\hline Alumina & 6 & 20.9 Mt alumina & & Alumina refinery & Huntly-Willowdale, Gove & \\
\hline Copper & 32 & 914,000 t $\mathrm{Cu}$ & open cut, underground & $\begin{array}{c}\text { Flotation, } \\
\text { Heap Leach (SX-EW) }\end{array}$ & $\begin{array}{l}\text { Mt Isa, Olympic Dam, Ernest Henry, Nifty, } \\
\text { Mt Lyell, Prominent Hill, Cadia Valley }\end{array}$ & $\begin{array}{c}\text { gold, silver, sulfuric acid, } \\
\text { magnetite }\end{array}$ \\
\hline Gold & 68 & $\sim 250 \mathrm{t} \mathrm{Au}$ & open cut, underground & $\begin{array}{c}\text { Carbon-in-Pulp, } \\
\text { Heap Leach, Flotation }\end{array}$ & $\begin{array}{l}\text { Kalgoorlie, Telfer, Boddington, } \\
\text { Cadia Valley } \\
\end{array}$ & silver, copper \\
\hline Iron Ore & 13 & 490.8 Mt saleable concentrate & open cut & Beneficiation & $\begin{array}{l}\text { Mt Newman, Mt Tom Price, Chichester, } \\
\text { Middleback Ranges, Savage River }\end{array}$ & none \\
\hline Lead-Zinc-Silver & 13 & $\begin{array}{c}648,000 \mathrm{t} \mathrm{Pb} \\
1,541,000 \mathrm{t} \mathrm{Zn} \\
1728 \mathrm{t} \mathrm{Ag} \\
\end{array}$ & open cut, underground & Flotation & $\begin{array}{l}\text { Mt Isa, Cannington, Broken Hill, Century, } \\
\text { McArthur River, Rosebery }\end{array}$ & gold, copper, sulfuric acid \\
\hline Manganese & 3 & $6.21 \mathrm{Mt}$ concentrate & open cut & Flotation & Groote Eylandt, Woodie Woodie & none \\
\hline Nickel & 9 & $246,000 \mathrm{t} \mathrm{Ni}$ & open cut, underground & Flotation & $\begin{array}{c}\text { Kambalda, Mt Keith, Leinster, } \\
\text { Murrin Murrin, Cosmos }\end{array}$ & cobalt, copper \\
\hline Tin & 3 & 6014 t Sn & underground & Flotation & Renison Bell & copper \\
\hline
\end{tabular}

Notes: All data updated from [21] and commonly from respective company annual and/or quarterly reporting; SX-EW—solvent extraction and electrowinning. 
Figure 1. Average ore grades of selected base and precious metals over time in Australian mineral resources (data updated from [21,22]). (a) Lead and zinc ; (b) gold, copper and silver.

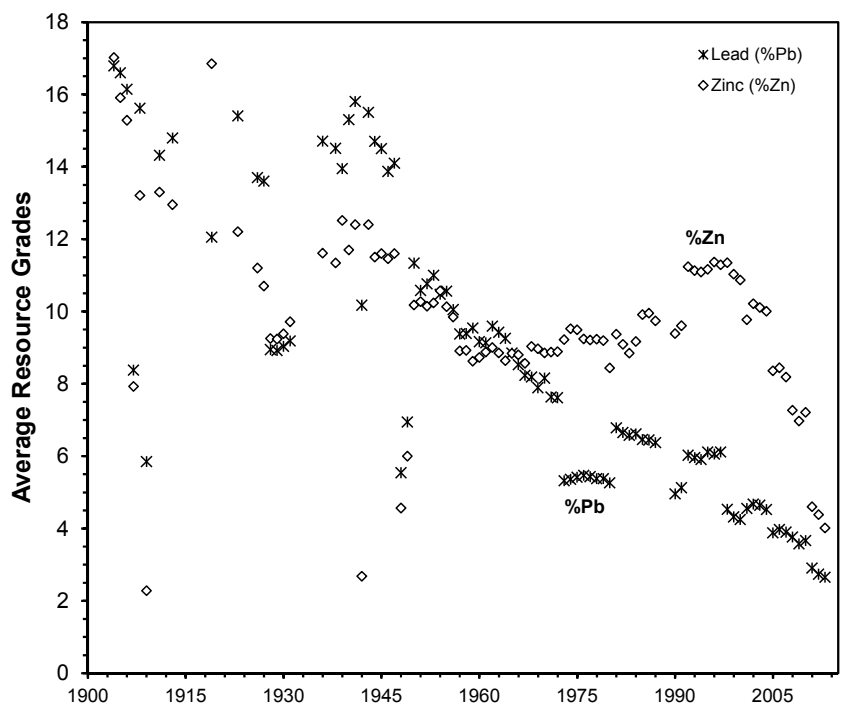

(a)

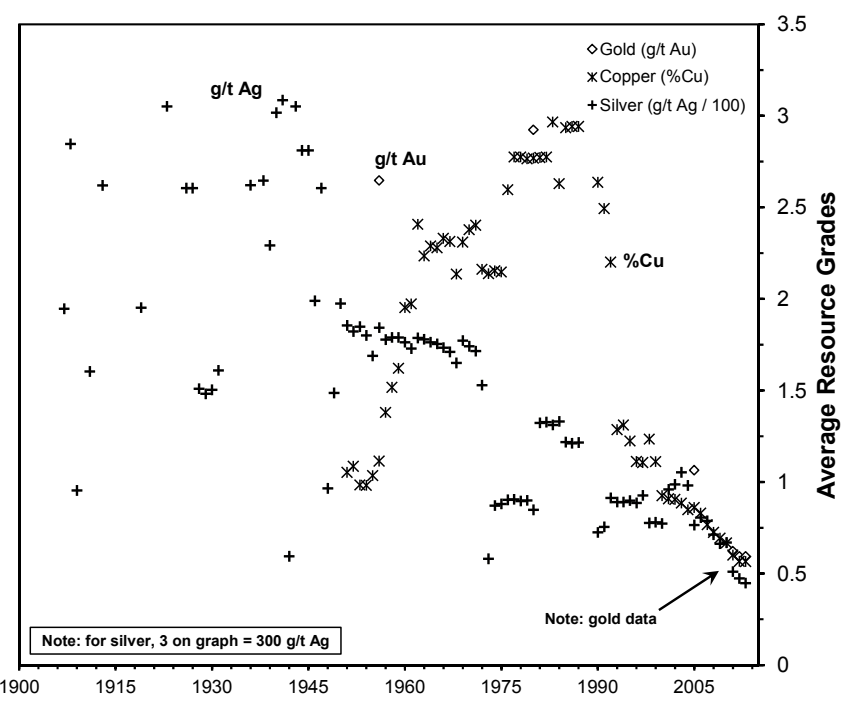

(b)

\subsection{Summary of Australia's Principal Mineral Resources by Major Commodity and Companion Metals}

A detailed assessment of Australia's mineral resources has been compiled, with almost all data derived from mining company annual reports and their estimates are developed using statutory mineral resource reporting codes. The results by major commodity and companion metals are shown in Table 4, and almost all of these mineral resource values are derived from high-quality data (i.e., a statutory code). In general, our deposit-by-deposit compilation agrees well with the national estimates by Geoscience Australia [23]. At present, all deposits have not been classified by their geology, mineralogy or formal mineral deposit type (e.g., see [13] for $\mathrm{Cu}$ ), with this to be completed in future research (only the split between sulfide and laterite ores has been done for $\mathrm{Ni}$ ).

An unusual aspect of iron ore is that many deposits also report impurity data such as alumina, phosphorous, silica or manganese, since low levels of impurities are critical to ensuring steel quality. The 17 low quality deposits in the Mn data set are all iron ore projects which report Mn, although it is not the primary metal of interest - and hence the low quality status. It demonstrates, however, that if such grades are reported, the contained Mn is some ten times Australia's 2012 Mn production. Likewise, the alumina in iron ores could constitute a sizeable resource if it was economically viable to separate for Al production.

The main problem, however, is that companion metals, other than the common metals already extracted, are rarely reported. The end result is that only a small fraction of the deposits have ore grade and tonnage data for companion metals. 
Table 4. Preliminary assessment of mineral resources in Australia by major commodity, and including potentially extractable companion metals (2012 data).

\begin{tabular}{|c|c|c|c|c|c|c|}
\hline $\begin{array}{c}\text { Primary/Host } \\
\text { metal(s) }\end{array}$ & $\begin{array}{c}\text { No. of } \\
\text { Mines/Deposits }^{\text {a }} \\
\end{array}$ & Mt ore & Ore grades & Contained metals & Possible companion metals & $\begin{array}{l}\text { National } \\
\text { estimate }^{b}\end{array}$ \\
\hline \multirow{2}{*}{ Bauxite } & $28(\mathrm{H})$ & 7059.2 & $\sim 42.0 \% \mathrm{Al}_{2} \mathrm{O}_{3}$ & $2967.8 \mathrm{Mt} \mathrm{Al}_{2} \mathrm{O}_{3}$ & \multirow{2}{*}{$\mathrm{Ga}, \mathrm{V}, \mathrm{Fe}$} & \multirow{2}{*}{$\begin{array}{l}9328 \mathrm{Mt} \\
\text { bauxite }\end{array}$} \\
\hline & $5(\mathrm{M})$ & 1340.5 & $\sim 50.1 \% \mathrm{Al}_{2} \mathrm{O}_{3}$ & $672.1 \mathrm{Mt} \mathrm{Al}_{2} \mathrm{O}_{3}$ & & \\
\hline \multirow{2}{*}{ Copper } & $162(\mathrm{H})$ & $23,015.3$ & $0.57 \% \mathrm{Cu}, \sim 0.34 \mathrm{~g} / \mathrm{t} \mathrm{Au}, \sim 1.6 \mathrm{~g} / \mathrm{t} \mathrm{Ag}$ & 131.8 Mt Cu; $7740 \mathrm{t} \mathrm{Au;} \mathrm{37,590} \mathrm{t} \mathrm{Ag}$ & \multirow{2}{*}{$\begin{array}{c}\mathrm{Mo}, \mathrm{Re}, \mathrm{Fe}, \mathrm{Pb}, \mathrm{Zn}, \mathrm{U}, \mathrm{REEs} \\
\mathrm{Co}, \mathrm{Ni}, \mathrm{Bi}\end{array}$} & \multirow{2}{*}{$136.8 \mathrm{Mt} \mathrm{Cu}$} \\
\hline & $41(\mathrm{M})$ & 663.2 & $0.34 \% \mathrm{Cu}, \sim 0.03 \mathrm{~g} / \mathrm{t} \mathrm{Au}, \sim 3.5 \mathrm{~g} / \mathrm{t} \mathrm{Ag}$ & $2.24 \mathrm{Mt} \mathrm{Cu} ; 2240 \mathrm{t} \mathrm{Au} ; 21,430 \mathrm{t} \mathrm{Ag}$ & & \\
\hline \multirow{2}{*}{ Gold } & $346(\mathrm{H})$ & $24,081.8$ & $0.58 \mathrm{~g} / \mathrm{t} \mathrm{Au}, \sim 1.4 \mathrm{~g} / \mathrm{t} \mathrm{Ag}$ & $14,018 \mathrm{t} \mathrm{Au} ; 34,148 \mathrm{t} \mathrm{Ag}$ & \multirow{2}{*}{$\begin{array}{c}\mathrm{Cu}, \mathrm{Pb}, \mathrm{Zn}, \mathrm{U}, \mathrm{Mo}, \mathrm{Fe}, \mathrm{Sb}, \mathrm{Bi} \\
\mathrm{Re}, \mathrm{Ni}, \mathrm{PGEs}, \mathrm{Ba}\end{array}$} & \multirow{2}{*}{$14,974 \mathrm{t} \mathrm{Au}$} \\
\hline & $182(\mathrm{M})$ & 230.9 & $1.74 \mathrm{~g} / \mathrm{t} \mathrm{Au}, \sim 2.2 \mathrm{~g} / \mathrm{t} \mathrm{Ag}$ & $401.8 \mathrm{t} \mathrm{Au} ; 514.4 \mathrm{t} \mathrm{Ag}$ & & \\
\hline Iron ore & $214(\mathrm{H})$ & 120,937 & $43.6 \% \mathrm{Fe}$ & $52.74 \mathrm{Mt} \mathrm{Fe}$ & $\mathrm{V}, \mathrm{Ti}, \mathrm{Cu}, \mathrm{Mn}$ & $\begin{array}{c}122,135 \mathrm{Mt} \\
\text { ore }\end{array}$ \\
\hline \multirow{2}{*}{ Lead-Zinc-Silver } & $91(\mathrm{H})$ & 1979.5 & $2.79 \% \mathrm{~Pb} ; 4.50 \% \mathrm{Zn} ; 49.1 \mathrm{~g} / \mathrm{t} \mathrm{Ag}$ & 55.28 Mt Pb; 89.01 Mt Zn; 97,130 t Ag & \multirow{2}{*}{$\begin{array}{c}\mathrm{Cu}, \mathrm{Au}, \mathrm{Ba}, \mathrm{Ni}, \mathrm{Pb}, \mathrm{Mo}, \mathrm{Co} \\
\text { W, In, Fe, Sn, Hg, Sb, F }\end{array}$} & \multirow{2}{*}{$\begin{array}{r}58.2 \mathrm{Mt} \mathrm{Pb} \\
91.9 \mathrm{Mt} \mathrm{Zn} \\
125,200 \mathrm{t} \mathrm{Ag}\end{array}$} \\
\hline & $28(\mathrm{M})$ & 99.5 & $1.71 \% \mathrm{~Pb} ; 2.13 \% \mathrm{Zn} ; 15.9 \mathrm{~g} / \mathrm{t} \mathrm{Ag}$ & $1.71 \mathrm{Mt} \mathrm{Pb} ; 2.12 \mathrm{Mt} \mathrm{Zn;} 1580$ t Ag & & \\
\hline \multirow{3}{*}{ Manganese } & $9(\mathrm{H})$ & 411.1 & $23.1 \% \mathrm{Mn}$ & 95.06 Mt Mn & \multirow{3}{*}{$\mathrm{Fe}$} & \multirow{3}{*}{$701 \mathrm{Mt}$ ore } \\
\hline & $8(\mathrm{M})$ & 14.1 & $22.4 \% \mathrm{Mn}$ & $3.16 \mathrm{Mt} \mathrm{Mn}$ & & \\
\hline & $17(\mathrm{~L})$ & 4365 & $0.50 \% \mathrm{Mn}$ & $21.76 \mathrm{Mt} \mathrm{Mn}$ & & \\
\hline \multirow{2}{*}{ Nickel sulfide } & $36(\mathrm{H})$ & 1638.3 & $0.66 \% \mathrm{Ni} ; \sim 0.02 \mathrm{Cu} ; \sim 0.002 \% \mathrm{Co}$ & $10.89 \mathrm{Mt} \mathrm{Ni} ; 0.31 \mathrm{Mt} \mathrm{Cu} ; 38.8 \mathrm{kt} \mathrm{Co}$ & \multirow{2}{*}{$\mathrm{Pt}, \mathrm{Pd}, \mathrm{Au}$} & \multirow{4}{*}{ 39.9 Mt Ni } \\
\hline & $21(\mathrm{M})$ & 463.3 & $0.30 \% \mathrm{Ni} ; \sim 0.31 \mathrm{Cu} ; \sim 0.012 \% \mathrm{Co}$ & 1.41 Mt Ni; $1.46 \mathrm{Mt} \mathrm{Cu} ; 55.1 \mathrm{kt} \mathrm{Co}$ & & \\
\hline \multirow{2}{*}{ Nickel laterite } & $25(\mathrm{H})$ & 1480.8 & $0.67 \% \mathrm{Ni} ; \sim 0.048 \% \mathrm{Co}$ & $9.89 \mathrm{Mt} \mathrm{Ni} ; 716$ kt Co & \multirow{2}{*}{$\mathrm{Sc}, \mathrm{Pt}$} & \\
\hline & $38(\mathrm{M})$ & 2884.2 & $0.78 \% \mathrm{Ni} ; \sim 0.047 \% \mathrm{Co}$ & $22.39 \mathrm{Mt} \mathrm{Ni} ; 1350 \mathrm{kt} \mathrm{Co}$ & & \\
\hline $\begin{array}{l}\text { Platinum group } \\
\text { elements }\end{array}$ & $8(\mathrm{H})$ & 454.1 & $\begin{array}{c}\sim 0.24 \mathrm{~g} / \mathrm{t} \mathrm{Pt}, \sim 0.25 \mathrm{~g} / \mathrm{t} \mathrm{Pd}, \sim 0.2 \mathrm{~g} / \mathrm{t} \\
\mathrm{Rh}, \sim 0.1 \mathrm{~g} / \mathrm{t} \mathrm{Au}, \sim 0.27 \% \mathrm{Cu} \\
\sim 0.28 \% \mathrm{Ni}\end{array}$ & $\begin{array}{l}\sim 109 \mathrm{t} \mathrm{Pt}, \sim 112 \mathrm{t} \mathrm{Pd}, \sim 90 \mathrm{t} \mathrm{Rh} \\
\sim 45 \mathrm{t} \mathrm{Au}, \sim 1.2 \mathrm{Mt} \mathrm{Cu}, \sim 1.3 \mathrm{Mt} \mathrm{Ni}\end{array}$ & \multirow[b]{2}{*}{$\mathrm{Ag}, \mathrm{In}, \mathrm{Zn}, \mathrm{Pb}, \mathrm{Fe}$} & $\begin{array}{l}276.1 \text { t PGEs } \\
(6 \mathrm{E})^{\mathrm{c}}\end{array}$ \\
\hline Tin & $\begin{array}{l}20(\mathrm{H}) \\
17(\mathrm{M})\end{array}$ & $\begin{array}{l}135.9 \\
294.1\end{array}$ & $\begin{array}{c}0.36 \% \mathrm{Sn} ; \sim 0.08 \% \mathrm{Cu} \\
\sim 0.05 \% \mathrm{WO} 3 \\
\sim 0.05 \% \mathrm{Sn} ; \sim 0.01 \% \mathrm{Cu} \\
0.16 \% \mathrm{WO} 3 \\
\end{array}$ & $\begin{array}{l}484.6 \mathrm{kt} \mathrm{Sn} ; 108 \mathrm{kt} \mathrm{Cu} ; 67.6 \mathrm{kt} \mathrm{WO} \\
133.6 \mathrm{kt} \mathrm{Sn} ; 16 \mathrm{kt} \mathrm{Cu} ; 479.5 \mathrm{kt} \mathrm{WO}_{3}\end{array}$ & & $635 \mathrm{kt} \mathrm{Sn}$ \\
\hline
\end{tabular}


To derive preliminary estimates of some important companion metals, separate summaries of mineral resources for scandium ( $\mathrm{Sc}$ ), antimony ( $\mathrm{Sb}$ ), molybdenum (Mo), rhenium ( $\mathrm{Re}$ ), indium (In), and zirconium ( $\mathrm{Zr}$ )-niobium ( $\mathrm{Nb}$ )-hafnium (Hf)-tantalum (Ta) were compiled, as shown in Table 5. Important notes for each metal include:

- Scandium: Sc is only reported in Ni laterite deposits in northern Queensland and central New South Wales, forming a potential co-product based on approximate market values for the $\mathrm{Sc}$, $\mathrm{Ni}$, and Co. No such projects have thus far been developed in Australia.

- Antimony: $\mathrm{Sb}$ is reported in a select few gold deposits across Australia, and although these projects are often old gold mining fields, they commonly struggle to remain profitable due to the difficulty in separating $\mathrm{Sb}$ from Au.

- Molybdenum: Mo resources have been increasing in recent years due to exploration success in finding new deposits across Australia. Historically, Australia has not been a Mo producer.

- Rhenium: Re is reported in only 2 deposits, both in Queensland. As with Mo, historically Australia has not been a Re producer either at its smelters/refineries or accounted for in exported ores or concentrates.

- Indium: As with $\mathrm{Sc}$ and $\mathrm{Re}$, In is only reported in 3 deposits, one each in Queensland, Tasmania, and New South Wales. No historic production or exports of In are known.

- Zirconium-Niobium-Hafnium-Tantalum: 4 deposits are reported, two each in Western Australia and New South Wales. They are all considered polymetallic projects which include rare earths and sometimes uranium, thorium, phosphate, and/or gallium. Historically, Australia has not mined and processed such complex polymetallic ores.

Table 5. Preliminary assessment of mineral resources for selected companion metals in Australia (2012 data).

\begin{tabular}{cccccc}
\hline Companion metal & Number of deposits & Mt ore & Ore grades & $\begin{array}{c}\text { Contained } \\
\text { companion metal }\end{array}$ & Other metals \\
\hline Scandium & $6(\mathrm{H})$ & 100.8 & $111 \mathrm{~g} / \mathrm{t} \mathrm{Sc}$ & $11,155 \mathrm{t} \mathrm{Sc}$ & $\mathrm{Ni}, \mathrm{Co}$ \\
Molybdenum & $16(\mathrm{H})$ & 7252.3 & $0.027 \% \mathrm{Mo}$ & $1935 \mathrm{kt} \mathrm{Mo}$ & $\mathrm{Cu}, \mathrm{Re}, \mathrm{Ag}, \mathrm{Pb}, \mathrm{Zn}, \mathrm{Au}$, \\
& $6(\mathrm{H})$ & 13.3 & $1.43 \% \mathrm{Sb}$ & $190.5 \mathrm{kt} \mathrm{Sb}$ & $\mathrm{U}, \mathrm{F}, \mathrm{W}, \mathrm{Co}, \mathrm{REEs}, \mathrm{V}$ \\
Antimony & $3(\mathrm{H})$ & 5.91 & $21.5 \mathrm{~g} / \mathrm{t} \mathrm{In}$ & $127.2 \mathrm{t} \mathrm{In}$ & $\mathrm{Cu}, \mathrm{Sn}, \mathrm{Ag}, \mathrm{Ag}, \mathrm{Zn}$ \\
Indium & $2(\mathrm{H})$ & 69.8 & $3.4 \mathrm{~g} / \mathrm{t} \mathrm{Re}$ & $235.7 \mathrm{t} \mathrm{Re}$ & $\mathrm{Mo}, \mathrm{Cu}, \mathrm{Au}, \mathrm{Ag}$ \\
Rhenium & & & $0.95 \% \mathrm{ZrO}_{2}$ & $1.93 \mathrm{Mt} \mathrm{ZrO}_{2}$ & \\
\hline & & & $0.021 \% \mathrm{HfO}_{2}$ & $43.1 \mathrm{kt} \mathrm{HfO}_{2}$ & $\mathrm{Ga}, \mathrm{Th}, \mathrm{U}, \mathrm{REEs}$ \\
Zirconium-Hafnium- & $4(\mathrm{H})$ & 202.1 & $0.43 \% \mathrm{Nb}_{2} \mathrm{O}_{5}$ & $877 \mathrm{kt} \mathrm{Nb}_{2} \mathrm{O}_{5}$ & \\
Niobium-Tantalum & & & $0.019 \% \mathrm{Ta}_{2} \mathrm{O}_{5}$ & $37.6 \mathrm{kt} \mathrm{Ta}_{2} \mathrm{O}_{5}$ & \\
\hline
\end{tabular}

In general, the ore grades and tonnages reported for the various deposits vary widely, from high grade-low tonnage (e.g., Merlin Mo-Re deposit) to larger tonnage-lower grade deposits (e.g., Kalman $\mathrm{Cu}-\mathrm{Mo}-\mathrm{Re}$ deposit). The very small number of deposits that report the ore grades of companion metals is somewhat surprising given Australia's major mining industry. It could perhaps be related to the small global market for such metals and to the lack of perceived value for these metals in exported (or processed) concentrates, although given the growing importance of such metals and their prospective 
value, this position will be difficult to maintain in the future. Another issue is the fact that most mining companies prefer to keep mineral processing focused on key commodities only, such as $\mathrm{Zn}, \mathrm{Sn}, \mathrm{Cu}$ or $\mathrm{Au}$ (e.g., the Olympic Dam project focuses on $\mathrm{Cu}-\mathrm{U}-\mathrm{Au}-\mathrm{Ag}$ only and ignores the potentially substantial value in REEs). The concentrates are produced for export (for the most part), whereas the companion metals would be extracted during smelting and/or refining a long distance from the mine and very separate to the mining company.

An important issue is that many existing mineral deposits are likely to contain companion metals, potentially even at economic concentrations, but they are not currently valued by mining companies in Australia or remain uneconomic at current market prices, demand levels and smelter/refinery configurations. For example, Australia's extensive bauxite resources doubtless contain substantial amounts of Ga. Similarly, widespread heavy mineral sands deposits contain the mineral monazite that can be a significant source of REEs. (Australia used to export monazite concentrates for this purpose until the Chinese REE supply made this uneconomic.) Numerous $\mathrm{Zn}$ and $\mathrm{Sn}$ deposits could be expected to contain In, while the expanding number of Mo deposits could be expected to contain variable amounts of Re.

\section{Estimating Companion Metal Production Potential}

The preliminary quantification of contained companion metals in Australian ores provides a starting point for estimating the maximum cumulative production of those metals. To see how this might be done, consider the flow diagram of Figure 2, which illustrates the principal steps involved in turning metals in ore into metals in products. The "ore resource" consists of companion metal atoms contained in Australian host metal deposits; this ore resource is comprised of mineralised ore, host metal, and the “contained companion metal" of Table 5, column 4.

Figure 2. Principal steps in the ore to metal in products sequence.

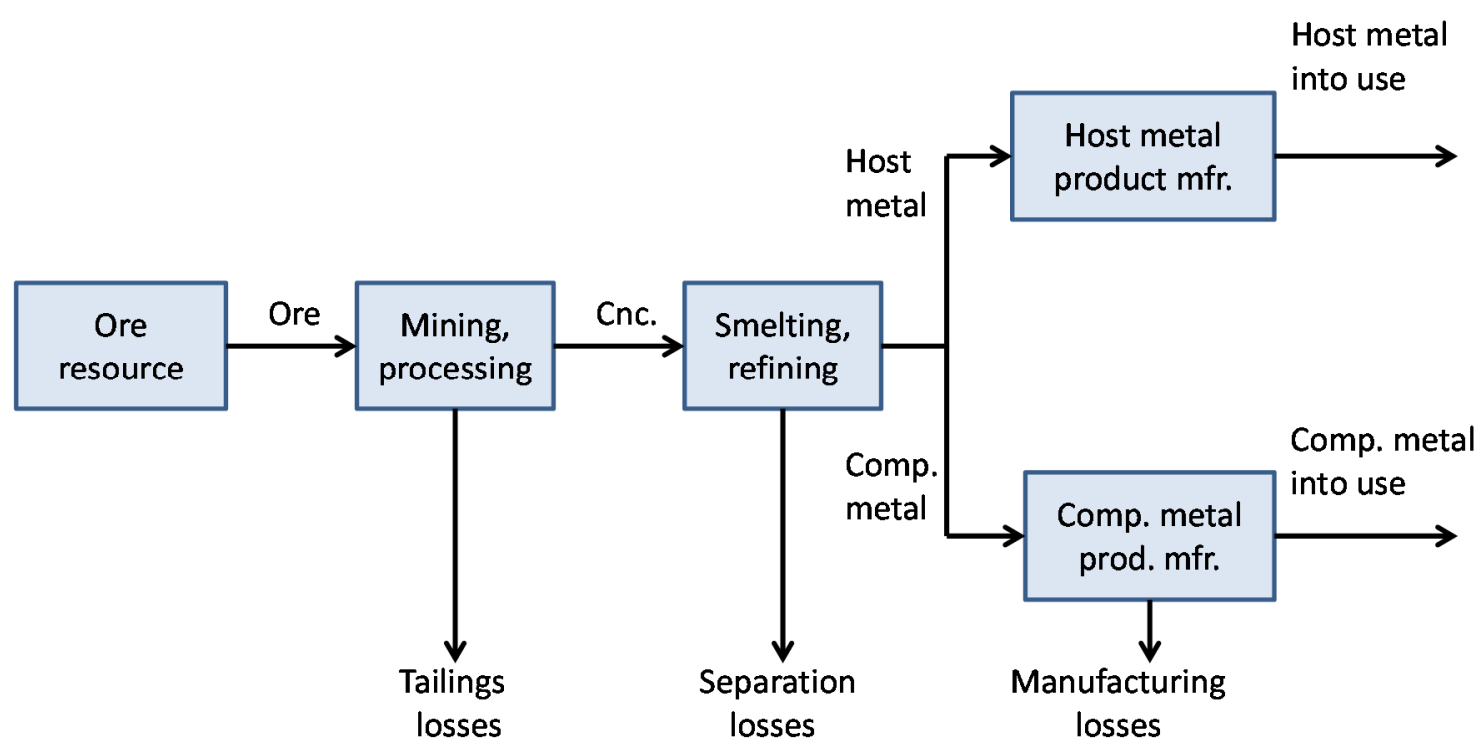

When mineral resources are mined and processed, some fraction of the companion metal or metals is lost to tailings. Smelting and refining of the "concentrates" (which takes several steps and could occur in Australia and/or elsewhere) creates further companion metal losses to slags. The separated 
metals then move on to manufacturing, where further losses occur. Typically, losses to tailings are much larger than those to slag, which in turn are larger than those in manufacturing.

The potential integrated production over time of a particular companion metal in Australian ores is given by:

$$
\mathrm{P}=\mathrm{M} \cdot \mathrm{r}_{\min } \cdot \mathrm{r}_{\mathrm{sm}} \cdot \mathrm{r}_{\mathrm{mfg}}
$$

where $\mathrm{M}$ is the contained companion metal quantity of Table $5 ; r_{\min }$ is the companion metal recovery efficiency from ore extraction and initial processing ("mining"); $r_{s m}$ is the companion metal recovery efficiency from smelting and refining; and $r_{\mathrm{mfg}}$ is the companion metal recovery efficiency from product manufacture.

At present, there is a lack of published data for Australia to allow such estimates to be presented (closely related to the low number of smelters and refineries in Australia). If typical values of the companion metal production efficiencies at different stages of the processing sequences are available, an estimate of the potential integrated production of the companion metal from Australian ores over time can be made, were all those ores to be processed so as to recover their contained companion metals.

At present, there is only one deposit in our data set which is a slag heap (the Zeehan slag in western Tasmania), with no data for tailings. Given the large scale of numerous metal mines across Australia, these tailings could constitute a very substantial body of companion metal resources. For example, the Broken Hill field has processed $215 \mathrm{Mt}$ ore grading $10 \% \mathrm{~Pb}, 10 \% \mathrm{Zn}$ and $150 \mathrm{~g} / \mathrm{t} \mathrm{Ag}$ (plus minor production of $\mathrm{Cu}$ and $\mathrm{Au}$ ), meaning that about $130 \mathrm{Mt}$ of tailings would remain at Broken Hill (after allowing for exporting of concentrates to smelters interstate or overseas) - even at lower grades this could represent a significant resource of various companion metals (e.g., In, Cd, Ge, etc.). The potential for recovery, of course, depends on technology, economics, demand, and the energy, water and chemical intensity of companion metal separation from tailings compared to those from operating mines and smelters/refineries. This issue is the same all over the world whereby tailings and slags from historic mining and smelters/refineries (and even operating projects) could be viewed as a potential companion metal resource-i.e., conceivable metal mines of the future.

Let's take Zn as an example. In 2012, Australian and global Zn mine production was about 1541 and 13,536 kt Zn, respectively, whilst Australian and global $\mathrm{Zn}$ refined production was about 498 and $12,589 \mathrm{kt} \mathrm{Zn}[2,20]$. Indium (In) is a critical companion metal which is almost entirely derived from $\mathrm{Zn}$ refineries [24]. For 2012, global refined In production was estimated to be $795 \mathrm{t}$ In [2] —in other words, a ratio of about 63 grams In per $\mathrm{t} \mathrm{Zn}$ metal. On this basis, Australia's $\mathrm{Zn}$ refineries could potentially have produced approximately $31.4 \mathrm{t}$ In with a further $65.9 \mathrm{t}$ In in exported concentrates - a total of $\sim 97.3 \mathrm{t}$ In. The approximate 2012 global price was US\$494,500/t refined In-meaning Australia's approximate annual In supply could be worth some Aus $\$ 49.5$ million (using an exchange rate of Aus\$1/1.0295\$US; [20]). This contrasts with the 2012 value of Australia's refined Zn production of Aus $\$ 981.2$ million and nominal Zn value in concentrates of Aus\$2,055 million (data from [20]). The value of In could therefore add a further $1.6 \%$ in economic value to the $\mathrm{Zn}$ industry.

At present, it is unclear whether the long-term decline in $\mathrm{Zn}$ grades for ores processed and reported mineral resources also holds true for companion metals. In global terms, the unit extraction of In from $\mathrm{Zn}$ has increase some 20-fold since 1982 (using data from [2,3]), suggesting there remains substantial 
scope for increasing extraction of companion metals from the $\mathrm{Zn}$ sector, although considerable further research into these issues remains to be done.

As an alternate example, let's examine the Olympic Dam project in South Australia. This is an unusual project in that it produces $\mathrm{Cu}, \mathrm{U}, \mathrm{Au}$ and $\mathrm{Ag}$ from a combined mine, mill, $\mathrm{Cu}-\mathrm{U}$ hydrometallurgical complex, $\mathrm{Cu}$ smelter and $\mathrm{Cu}$ refinery. The super-giant deposit is well known to contain rare earth elements (see [18]) although these are not currently being extracted with no proposals by owner BHP Billiton to do so. In 2012, total $\mathrm{Cu}-\mathrm{U}-\mathrm{Au}-\mathrm{Ag}$ mineral resources were reported to be $9576 \mathrm{Mt}$ grading $0.82 \% \mathrm{Cu}, 0.026 \% \mathrm{U}_{3} \mathrm{O}_{8}, 0.31 \mathrm{~g} / \mathrm{t} \mathrm{Au}$ and $1.4 \mathrm{~g} / \mathrm{t} \mathrm{Ag}$ (an additional Au only mineral resource is also reported, $364 \mathrm{Mt}$ at $0.75 \mathrm{~g} / \mathrm{t} \mathrm{Au}$ ) [25]. For 2012, the combined value of $\mathrm{Cu}-\mathrm{U}-\mathrm{Au}-\mathrm{Ag}$ production was approximately Aus\$1,834 million (data combined from BHP Billiton quarterly reporting and [20]). For the reported mineral resource, an approximate grade can be estimated of $\sim 0.48 \%$ rare earth oxides [18], a price of $\sim \$ 30,000 / \mathrm{t}$ rare earth oxides (REOs) (price from [3]) and assuming $\sim 10 \mathrm{Mt} /$ year of ore processing at $50 \%$ recovery of rare earths, this means that annual production could be $\sim 24,000 \mathrm{t}$ REOs valued at Aus $\$ 720$ million - a substantial source of additional revenue and value. In addition, using the same economic values, the combined value of $\mathrm{Cu}-\mathrm{U}-\mathrm{Au}-\mathrm{Ag}$ in reported mineral resources is some Aus $\$ 999$ billion compared to REOs at Aus $\$ 1379$ billion - a significant contrast.

Overall, this paper has compiled a unique and comprehensive data set of reported host and companion metal resources in Australia for 2012 based on formally reported mineral resources - and arguably the first such robust data for companion metals. Unlike some commercial or government databases, however, this data is publicly available and complete (i.e., data includes ore tonnages and grades and not just metal totals alone), which allows greater rigour and scrutiny as well as use for subsequent analyses and modelling purposes by any researchers. It is clear that there is considerable potential to expand the resource base based on existing deposits which could contain companion metals, new deposit discoveries and examining tailings/slags for potential resources. Future companion metals research will examine mining and mineral processing in more detail, to ascertain typical recovery factors during these stages, as well as potential resources in exported concentrates and assess the potential for tailings and slags as future sources. Other research being conducted in parallel to this work will examine the flows of companion metals in manufacturing and recycling. Finally, the combined research will be able to produce a comprehensive account of the flow of companion metals in Australia from mineral resource to metal to product and recycling, a full materials flow of uses, imports and exports-i.e., cradle to cradle - arguably the first such national account for companion metals based on thorough and robust data.

\section{Conclusions}

Ores that are typically mined for the major metals generally contain a variety of trace metals that we have termed companion metals. In the present work we carried out preliminary estimates for the amounts of several of the companion metals in Australian ores. We also demonstrated the approach that can be taken to convert those estimates into potential quantities of companion metals that can be produced from those deposits. Much of the necessary information needed to validate these estimates and to compare them with global stocks and flows of these metals is not routinely available. Although the reasons for this are not clear, possible explanations include the lack of recognition of the potential 
value, the focus by companies on host metals, lack of sufficient data, or the smaller market size for companion metals. Nonetheless, the results presented above indicate that the value of the companion metals in Australian ores could be substantial, that it is not being fully taken advantage of, and that opportunities may exist for a wider scope of natural resources than has traditionally been assumed.

\section{Acknowledgments}

This research is supported by Australia's CSIRO under the Flagship Collaboration Cluster "Wealth from Waste", a joint program between University Technology Sydney (UTS), Monash University, University of Queensland, Swinburne University, Yale University and CSIRO. Additional insights from anonymous reviewers, Simon Jowitt, Zhehan Weng and Tim Werner are greatly appreciated and acknowledged.

\section{Author Contributions}

Gavin M. Mudd conducted a rigorous literature review, collected the data from various sources and analysed and prepared the manuscript for submission. He also contributed significantly to the discussion of the paper and coordinated the overall aspects of the paper until its final publication. Addressed the reviewer's comments and contributed to prepare and finalise published version.

Mohan Yellishetty helped with data compilation on mineral resources, especially iron ore, helped with discussion and final editing of the paper.

Barbara K. Reck reviewed and commented for improvement of final version and contributed to prepare and finalise published version. Also, contributed towards discussions on scarce metals and the concept of host and companion metals and helped improve the overall quality of the paper.

Thomas E. Graedel reviewed and suggested a few edits to improve the paper. He also prepared the schematic of figure and formulated the empirical equation to estimate the potential integrated production over time of a particular companion metal in Australian ores.

\section{Conflicts of Interest}

The authors declare no conflict of interest.

\section{References}

1. Graedel, T.E.; Barr, R.; Chandler, C.; Chase, T.; Choi, J.; Christoffersen, L.; Friedlander, E.; Henly, C.; Jun, C.; Nassar, N.T.; et al. Methodology of metal criticality determination. Environ. Sci. Technol. 2012, 46, 1063-1070.

2. US Geological Survey. Minerals Yearbook; Years 1994 to 2011; US Geological Survey (USGS): Reston, VA, USA, 1994-2011.

3. US Geological Survey. Minerals Commodity Summaries; Years 1996 to 2014; US Geological Survey (USGS): Reston, VA, USA, 1996-2014.

4. Rankin, W.J. Minerals, Metals and Sustainability-Meeting Future Material Needs; CSIRO Publishing and CRC Press: Melbourne, Australia, 2011. 
5. Spitz, K.; Trudinger, J. Mining and the Environment-From Ore to Metal; CRC Press, Taylor \& Francis Group: London, UK, 2008; p. 891.

6. Crowson, P.C.F. Mineral reserves and future minerals availability. Miner. Econ. 2011, 24, 1-6.

7. US Geological Survey. Minerals Commodity Summaries 2014; US Geological Survey (USGS): Reston, VA, USA, 2014; p. 199.

8. AusIMM; MCA; AIG. Australasian Code for Reporting of Exploration Results, Mineral Resources and Ore Reserves: The JORC Code; Joint Ore Reserves Committee (JORC) of The Australasian Institute of Mining and Metallurgy (AusIMM), Minerals Council of Australia (MCA) and Australian Institute of Geoscientists (AIG): Parkville, VIC, Australia, 2004; p. 20.

9. Stephenson, P.R. The JORC code. IMM Trans. B Appl. Earth Sci. 2001, 110, B121-B125.

10. South African Mineral Resource Committee. South African Code for Reporting of Mineral Resources and Mineral Reserves; South African Mineral Resource Committee (SAMREC) Working Group: Johannesburg, South Africa, 2007, p. 65.

11. Ontario Securities Commission. National Instrument 43-101-Standards of Disclosure for Mineral Projects, Form 43-101F1 and Companion Policy 43-101CP; Ontario Securities Commission (OSC): Toronto, Canada, 2011; p. 44.

12. Jowitt, S.M.; Mudd, G.M.; Weng, Z. Hidden mineral deposits in Cu-dominated porphyry-skarn systems: How resource reporting can occlude important mineralization types within mining camps. Econ. Geol. 2013, 108, 1185-1193.

13. Mudd, G.M.; Weng, Z.; Jowitt, S.M. A detailed assessment of global $\mathrm{Cu}$ resource trends and endowments. Econ. Geol. 2013, 108, 1163-1183.

14. Mudd, G.M.; Weng, Z.; Jowitt, S.M.; Turnbull, I.D.; Graedel, T.E. Quantifying the recoverable resources of by-product metals: The case of cobalt. Ore Geol. Rev. 2013, 55, 87-98.

15. Mudd, G.M.; Jowitt, S.M. A detailed assessment of global nickel resource trends and endowments. Econ. Geol. 2014, 109, 1813-1841.

16. Mudd, G.M. Key trends in the resource sustainability of platinum group elements. Ore Geol. Rev. 2012, 46, 106-117.

17. Mudd, G.M. The future of yellowcake: A global assessment of uranium resources and mining. Sci. Total Environ. 2014, 472, 590-607.

18. Weng, Z.; Jowitt, S.M.; Mudd, G.M.; Haque, N. A detailed assessment of global rare earth resources: Opportunities and challenges. Econ. Geol. 2014, in Press.

19. Australian Bureau of Agricultural and Resource Economics. Australian Commodity Statistics; Years 1995 to 2010; Australian Bureau of Agricultural and Resource Economics (ABARE): Canberra, ACT, Australia, 1995-2010.

20. Bureau of Resource \& Energy Economics. Resources and Energy Statistics; Years 2011 to 2013; Bureau of Resource \& Energy Economics (BREE): Canberra, ACT, Australia, 2011-2013.

21. Mudd, G.M. The environmental sustainability of mining in Australia: Key mega-trends and looming constraints. Resour. Policy 2010, 35, 98-115.

22. Mudd, G.M. The Sustainability of Mining in Australia: Key Production Trends and Their Environmental Implications for the Future; Department of Civil Engineering, Monash University and Mineral Policy Institute: Melbourne, VIC, Australia, 2007; p. 277. 
23. Geoscience Australia. Australia's Identified Mineral Resources 2012; Geoscience Australia (GA): Canberra, ACT, Australia, 2013; p. 172.

24. Schwarz-Schampera, U. "Indium". In Critical Metals Handbook; John Wiley \& Sons: Chichester, UK, 2014; pp. 204-229.

25. BHP Billiton Ltd/Plc. Annual Report; BHP Billiton Ltd/Plc (BHPB): London, UK; Melbourne, VIC, Australia, 2012.

(C) 2014 by the authors; licensee MDPI, Basel, Switzerland. This article is an open access article distributed under the terms and conditions of the Creative Commons Attribution license (http://creativecommons.org/licenses/by/4.0/). 